\title{
TEACHING ABOUT DYING AND DEATH: THE 1918 FLU EPIDEMIC IN SOUTH AFRICA
}

DOI: http://dx.doi.org/10.17159/2223-0386/2020/n24a9

Rob Siebörger

Barry Firth

University of Cape Town

Cape Town, South Africa

Cape Peninsula University of Technology

Rob.Sieborger@uct.ac.za

Cape Town, South Africa

firthb@cput.ac.za

ORCID No.:0000-0003-1016-4511

ORCID No.: 0000000294630163

\section{Abstract}

It seems obvious that while others around us are concerned with trying to understand the nature of the COVID-19 pandemic and the ways in which it has disrupted so much of our lives and professional work, history educators should be concerned rather to look back, to study previous epidemics for the light that they can shed on today. The 1918 'Spanish' flu is a logical starting place. But it presents two obstacles: first, that there is so little that is truly comparable to the 2020 experience and, secondly, that the material of 1918 in South Africa is potentially so difficult to use in the classroom. How does one, for instance, teach about the number of cases where people narrowly avoided being buried alive, escaping in the nick of time. (And what about those who were not as fortunate?)

This is an exploration of uncharted territory that presents an initial map to anyone who might be tempted to follow suit and put it to the test. As there is no ready model at hand to use to teach about dying and death in the history classroom, a sequence of five themes is proposed as a way in which one can approach the issue of mortality without coming at it head-on. The themes are explained and justified and an exemplar of a possible class activity is provided for each. The question posed is whether one should teach about dying and death in this way. The conclusion suggests what the possible benefits accruing might be.

Keywords: 1918 flu epidemic; Influenza; Spanish flu; COVID-19; Dying; Death; History curriculum; Human dignity; Empathy; Remembrance.

Drew Gilpin Faust wrote, "Mortality defines the human condition", (Faust, 2008:xi) as the introductory sentence to her study of death and the American Civil War. Yet it finds no real place in the history classroom. While wars and disasters, plagues and genocides, civil struggles and systematic internment find places in the history curriculum, it is very seldom that mortality is ever 
confronted directly. ${ }^{1}$ Death is treated by means of causes and results, statistics, literary works, film and video, and honour and remembrance, but it almost always remains at arm's length and is not openly addressed nor studied per se. The reasons are easy to find. Mortality is too heavy and difficult, death is a topic for the aging not the youth and death has an overarching finality - it can't lead anyone into the future.

The COVID-19 pandemic in 2020 has drawn attention to plagues and epidemics in the past, most notably the Black Death $\left(14^{\text {th }}\right.$ century Europe) and the 1918 "Spanish" influenza. There is, however, one major difference between the 2020 pandemic and the flu of a century ago in South Africa. In 2020 there has been a significant recovery rate and deaths constitute only around $1 \%$ of the number of infections. Its first wave of infection lasted approximately six months and there were fewer than 20,000 deaths $(0,03 \%)$ of the population of the country). By contrast, in $191842 \%$ of the total population (six million) of the country contracted the flu and at least two percent $(139,471)$ and likely as much as six percent $(350,000)$ of the total population had died within four weeks in October. ${ }^{2}$ It is impossible to study the 1918 epidemic without staring death in the face and coming to terms in some way with the utter devastation that the disease wrought over a very short period. So quickly and unexpectedly could it strike that one observer remembered having spoken to someone who was "hale and hearty and fit" at four p.m. but whom he discovered the next day had been buried at six a.m. He concluded: "He had succumbed very quickly overnight" (Phillips, 2018:122).

The question is whether it is reasonable to teach about dying and death on this scale in the classroom. In the absence of any models for considering this, ${ }^{3}$ we offer a sequence of five themes that opens the subject of mortality to study and investigation in secondary school history classes without dwelling on death in the first instance. They are:

1 The closest example in South African history is arguably the concentration camps in the South African war (Grade 10 Curriculum and Assessment Policy Statement (DBE, 2011:18)). Textbooks typically give statistics and a few photographs of the camps, but generally avoid addressing death and dying directly. The coverage of the Holocaust and World War I is often of a similar nature. Hammond (2001:21) raises the question of whether some historical atrocities have been judged more historically significant than others.

2 "Official" figures, as given in the Standard Encyclopaedia of Southern Africa, are: White cases $=454$ $653(17 \%$ of the cases), non-White cases $=2162152(83 \%$ of the cases $)$; White deaths $=11726(8,4 \%$ of deaths), non-White deaths $=127745$ (91,6\% of deaths). Howard Phillips estimates 300-350,000 deaths (Phillips, 2018:x). The world figure he provides is 50 million deaths, compared with 12-14 million deaths in World War I.

3 I have been unable to trace any studies that concern the teaching of dying and death in history teaching specifically. 
- Community concern and kindness;

- $\quad$ Health and medical care;

- Human dignity;

- $\quad$ Empathy with the suffering and bereaved;

- Remembrance.

In each case an exemplar activity ${ }^{4}$ is presented and discussed using oral and written source material that details the scale and horror of October 1918. As it is freely available and an excellent resource, the sources are all taken from Howard Phillips' 2018 book In a time of plague. Memories of the 'Spanish' Flu epidemic of 1918 in South Africa (Phillips, 2018). ${ }^{5}$

\section{Introductory information about the 1918 Flu epidemic}

"World in the Grip of "Flu". Epidemic on Three Continents. 180,000 Cases in Germany: 100,000 Victims in Budapest... Statement by Union Health Department. One of the Most Infectious Diseases Known: But Rapidly Destroyed by Sun and Fresh Air. Little Risk of Infection Out of Doors...." So read the headlines on the front page of the Kimberley newspaper the Diamond Fields Advertiser on 10 October 1918 (Alhadeff, 1976:35). From first detection in 1915 there had been instances of an unusually virulent strain of influenza related possibly to the millions of soldiers and sailors waging World War I under confined conditions at the time. It re-appeared in the United States in 1917 in a military camp. The first wave of the disease was relatively mild, but a second, highly infectious, wave began in August 1918. This so-called "Spanish" flu broke out in Freetown Sierra Leone, amongst other wartime ports. From there it was spread to Cape Town by two troopships returning from Europe, despite an attempt to quarantine the soldiers before they were allowed to go to their homes. From Cape Town the disease was spread along the railways into rural and urban communities all over South Africa. It wasn't only spread through returning soldiers and their contacts, however. People who fled towns and villages to try to escape it ended up taking the disease with them wherever they went. Migrant workers on the mines left to go to their homes in rural areas, spreading it on the way. Poorer communities especially were

4 The article explores the pedagogic issues and theoretical principles raised, which it does by proposing the sequence of five possible illustrated themes, but it is not an account of practice or classroom research. The exemplars simply illustrate how the themes might be applied.

5 A collection of interviews of and letters from people (1972-1983) who remembered the epidemic and wanted to share their reminiscences. The material was previously used in his PhD thesis (Phillips, 1990) and in a monograph (Phillips, 2012). 
impacted (Phillips, 2018:x-xii).

This provides the historical background for an introductory exercise once the sources below ${ }^{6}$ have been studied.

\section{Source extracts from interviews and letters that provide the information for the discussion and activities which follow:}

1. Whole families in a cottage were deceased and nobody would know about it. Whole families lay dead for days without anybody knowing .... And so whole houses, whole families just died out. ... Now we don't know how many people died, but we do know that not all of them were buried [in cemeteries]. I believe - it was reported and I believe - that thousands of them were simply buried in graves dug on the beach in the sand and that they are still there. Long trenches were dug and bodies wrapped; they couldn't use coffins - there were no coffins .... They couldn't keep up [the supply of coffins]. Can you imagine - from ten to 600 ?

Flu is not that. That [Spanish flu] is not- flu at all ... [Ordinary flu starts with] temperature, headache, pain in the back, pain in the muscles, and that's all. That's it. Occasionally there is a. kind of sore throat which [leads to a] secondary infection [which develops] into bronchitis or pneumonia and that would be that. [But] the toxicity of the [Spanish flu] virus became so strong that people died. It gave them no chance ....(Phillips, 2018:18). ${ }^{7}$

2. ... it felt as though Death was hovering above the city with his dark wings outspread waiting for further victims.

Rich and poor - those who could walk - pulled together; bodies were wrapped in sack-cloth or blankets, and the dead, rich and poor, were placed in long trenches in the cemetery. People just fell down in their tracks.

Transport on trams was free, and a communal soup kitchen had been set up in the City Hall where free soup was supplied for stricken families. "Society" women and others stood side-by-side to fill jugs with soup.

Three times a day, as a very small boy I would hurry with a large jug to the soup kitchens at the City Hall, and hurry back to my stricken family before the soup could become cold.

Doctors gave their services free, as did volunteers. Daily one house after the other would be entered to see if people were still alive - often it "would be found that entire families were found .... dead!” (Phillips, 2018:92). ${ }^{8}$

3. In one house, we found the parents dead and a young... girl in another room, very sick indeed. She was delirious. We washed her, gave her some

6 Phillips (2018:132-133) also includes 16 pages of photographs and copies of documents, which may also be used appropriately to illustrate hospitals and temporary flu care, food and medicine queues, burials and orphans.

7 Verbatim interview with Dr Max Cohen (born 1902). Interviewed on 22 April 1980. [Refers to Cape Town.]

8 Letter from Maurice Kaye (born 1910), 6 November 1978. [Refers to Kimberley.] 
soup and called again the next day. That second week was one I shall not forget. She seemed slightly better but did not want us to leave her. She clasped my hand and, with tears streaming down her cheeks, she begged me, "Doctor, you must save me". That was the only time I was ever called a doctor. So time passed, day out, day in. She was improving but we still had our duty to perform. The fifth day arrived when I had to tell her that her parents were both dead. That was the most heartrending moment of my life, having to take that sobbing girl in my arms (Phillips, 2018:74). ${ }^{9}$

4. We didn't know where the germs were; we didn't know if the germs were in drains or anything like that. We knew it was contagious, but coming in [to] direct contact with a person, but it was more than that; it could have been airborne too. It must have been airborne because it just went through a street just like that, as I said, it was like a fire out of control, out of control .... You know, you get some people who would put up their ... if they spoke to you, you know, they put up their hands across their mouth like that. That often happened. But then people said, "Well, if I'm going to get it, I'm going to get it, that's all", Yes, there was, there was definitely [a feeling] of fatalism, lots of that: "If I'm going to get it, I'm going to get it", you know. That was the general outlook ....(Phillips, 2018:72). ${ }^{10}$

5. A white man who had a shop or factory nearby (and who was married to a coloured woman) distributed lemons and milk from door to door, irrespective of who the inhabitants were. He also arranged to set up a soup distribution depot where soup made by the Muslim community was provided at 12 o'clock every day. This arrangement was made "in the heart of the epidemic". Strained soup and lemons (at "fever time") became usual fare for the sick (Phillips, 2018:13). ${ }^{11}$

6. Do you know wild garlic? ... We took that and cut off chips, just like .... potatoes. And then ... we put it in a rag ... and placed it around our bodies and made sure it was firmly stuck on us. Then it stayed there. Now, if it remained there for 24 hours and you took it off, then you could squeeze it. It drew all that poison ... from the epidemic .... (Phillips, 2018:90). ${ }^{12}$

7. Any doctors that were available were on duty. All [that] people were required to do was to tie a red rag, ribbon, anything, so long as it was red, tie it outside on a pillar, gatepost or something on the verandah ... and you tie a ribbon outside, then any passing doctor or somebody would notify, I suppose, the health authorities that such and such a house, number so-and-so ... and the doctor would come. If you were so bad again and you had a death and you couldn't do anything about it, you tied a black ribbon outside and

9 Letter from Mr NA Reinbach (born c. 1899), 14 May 1972. [Refers to Cape Town.]

10 Verbatim interview with Stan Stone (born 1905). Interviewed on 3 November 1978. [Refers to Cape Town.]

11 Notes from an interview with Gadja Gafiel-Cader (born 1899). Interviewed on 12 October 1983. [Refers to Cape Town.]

12 Verbatim interview with Joyce Kay (born 1908 or 1909). Interviewed on 26 May1978. [Refers to Kimberley.] 
then somebody would come along and see what could be done [to remove] the corpse (Phillips, 2018:34). ${ }^{13}$

8. It was a heartbreaking duty to go round seeing dead bodies. Some people just lay in bed - they knew nothing about fresh air - and their family would tend them and kiss them, quite oblivious of the danger. Many of these were not very fond of fresh air". When he [the interviewee] went around he was told to wear a calico mask before visiting very sick people. These masks were issued by the municipality(Phillips, 2018:120). ${ }^{14}$

9. ... the schools were closed for the holidays, as it was Michaelmas [the end of September]. As the Epidemic got worse the schools were closed \& turned into hospitals, anyone who could make a bed, prepare a tray or make soup \& beef tea was ever so welcome to help at these hospitals.

We knew the caretaker at the cemetery ..., when the epidemic was at its worst, [his wife] gave the Anglican minister a room at their house at the cemetery, I heard her say she felt so sorry for the minister, as he conducted funerals from Sunrise to Sunset. It was a time when people remained indoors unless they were helping a house full of sick people (Phillips, 2018:110). ${ }^{15}$

$10 . .$. my father [who was a doctor] asked me to come out with in his car (a little 2-seater runabout called the Saxon). School had closed down.

He would start on his rounds at 7.30 in the morning, and would get into a street to see his first patient. As he emerged, he would be pulled into house after house, and I would follow after him driving the car. On one occasion, after he came out of a house in District Six, he told me that there were several people dead inside.

And so it would go on. Time meant nothing, we would get home for a bite and then be off again through the traffic-empty streets. Visits would not stop until after midnight. And even then he wouId be called for some emergency from his bed (Phillips, 2018:48). ${ }^{16}$

11. De Beers [diamond mining company in Kimberley] Compound was very badly hit. There weren't enough coffins for the bodies which were driven in an open van with a bucksail thrown over them to the cemetery. ... sleeping facilities in compounds were very poor. Workers slept on boards, one above the other, with many in the same room and sometimes more than one in the same bed. When black [African] corpses were driven to the cemetery, he [the interviewee] could see bodies shaking underneath the tarpaulin. At thecemetery they were buried in trenches and covered with quicklime. Whites had coffins, but the undertakers could not cope

13 Verbatim interview with John Granger (born 1879). Interviewed on 14 June 1978. [Refers to Cape Town.]

14 Notes from an interview with Charles Kohler (born c. 1907). Interviewed on 23 January 1981. [Refers to Bloemfontein.]

15 Letter from Edna Aldworth (born 1906), October 1978. [Refers to Bloemfontein.]

16 Letter from Dr Robert Lane Forsyth (born 1904), 2 November 1978. [Refers to Cape Town.] 
with individual funerals and so, many whites" coffins were heaped on top of each other and driven like that to the cemeteries (Phillips, 2018:84). ${ }^{17}$

12. And then, I think afterwards there wasn't even anybody to make coffins or there wasn't any, enough wood. They just rolled people in blankets, any kind of, whatever they could and ... eventually they buried them in trenches, mass graves, common graves .... I remember going up to the butcher shop up the road and seeing the cart- Scotch carts .... Once or twice it wasn't just one body, but bodies piled on top of one another and what numbed me - it was heartbreaking - you could see a foot sticking out of the bottom because you know they hadn't properly wrapped up, just wrapped up any old how and buried in the graves. I am sure lots of people didn't even know where their people were buried. And that's how it went on as far as I can remember (Phillips, 2018:91). ${ }^{18}$

13. And they were poor, anyhow some of them in a very, very poor condition and they lived under terrible circumstances. And that was the first time I'd met death, you know. I'd hardly got inside [one of the houses] and a man fell dead on my feet. And I got used to [it] at that time. And they lived in terrible quarters, many of them barely underground, with just the only ventilation the door as you went in, with an opening (Phillips, 2018:57). ${ }^{19}$

14. A regiment of soldiers dug graves all day in the Woltemaad [sic, Cape Town] Cemetery which is miles long. They were replaced as they too fell ill. Ministers of religion stood by continuously for burial services, wood ran out so coffins could not be made, and the bodies of rich and poor alike were sewn up in sacking. The dead were laid out on the pavements and a cart transported them for burial.

In the Cape Peninsula at the peak of this terrible scourge there were ten thousand deaths in a fortnight (Phillips, 2018:53). ${ }^{20}$

15. I heard that one of my dearest and closest friends, a big well-built chap, of my own age, 20, who was an agricultural student in the Malmesbury district and working on a farm - he was always in the pink of health - had died of the flu. This shocked me so deeply that I felt that it did not matter to me now in the least if I got the flu and died too. In fact I even hoped I would!

But despite the constant stream of coughing and deeply saddened, tearful people standing before and around me in that small room and stricken area, I did not even sneeze (Phillips, 2018:72). ${ }^{21}$

17 Notes from an interview with Dudley Drever (born 1903). Interviewed on 20 November 1980. [Refers to Kimberley.]

18 J Kay (born 1908 or 1909), verbatim interview, 26 May 1978. [Refers to Kimberley.]

19 ME (Majorie) McKerron (Doctor, born 1895), verbatim interview, 15 December 1978. [Refers to Cape Town.]

20 Letter: C de Maire St Ledger, Sister Mary of the Sacred Heart (born 1870), 30 May 1972. [Refers to Cape Town.]

21 Letter: G August van Oordt (born 1898), 23 January 1982. [Refers to Cape Town.] 


\section{Introductory activity (after having read the introductory information and the sources)}

This, it is suggested, might take the form of a classroom debate.

Class divides into two (for and against) to debate the following motion:

No-one should be blamed for the suffering and death caused by the 1918 flu epidemic in South Africa.

The choice of a debate enables a tension to be set up amongst learners, who will be anxious above all to win the debate [a judge(s) should be appointed to adjudicate], rather than to discuss issues of dying and death. But, as they search for arguments to be made on either side, they will be exposed to the deeper issues that the sources bring to light. Assessing blame in this debate is both a neutral activity (in that it does not make much difference which side one is on) and one which removes much of the immediate attention from the circumstances of the flu victims. Greater depth of detail will come in the activities to follow.

\section{Community concern and kindness}

The circumstances of October 1918 are not entirely bleak. There is much comfort and personal moral challenge to be derived from the events. This enables a less demanding approach to the evidence and is intended to strengthen the grasp of the contents of the sources while encouraging students to look at the positive aspects in the sources.

By group discussion, by individual writing or by both. Divide the class into five sections, each being given one of the following topics:

- What practical things did people do help the victims of 'flu?

- What part was played by religious belief?

- What remedies did people believe would help keep the 'flu away from them, or help them survive when they got the 'flu?

- What did the government authorities do?

- What risks did people take?

Study the information provided and report your thoughts about your topic. $^{22}$

22 Here, and with the other four activities to follow, teachers would need to provide further instructions and specific guidance for their class should they trial this exercise (how much time to devote to it; to use all or only some of the sources; group and pair work; how much writing expected; per group or per individual, etc.) 


\section{Health and medical care}

This theme has an important role to play. It gives students the greatest opportunity to apply their knowledge, experience and understanding of the circumstances of the COVID-19 pandemic to 1918 epidemic. They will inevitably find that there is much that is not comparable ${ }^{23}$ and are also likely to make many mistakes. The reality is that they know what maskwearing is like, that they understand how people can go hungry during an epidemic, that they appreciate the role that doctors, hospitals and medical equipment can play, that they know what it is to have a government that is incapable of managing the crisis well and that they are familiar with the risks that some people take on behalf of others and the risks that face the poor in particular. The table below facilitates open-ended responses to both the 1918 and the 2020 circumstances. It is likely that there will be quite wide-ranging differences between the responses of students, which can be an aid to recognising that feelings about dying and death might vary considerably from person to person. The exercise is:

What has changed in the century since the 1918 'flu epidemic?

Complete this table, to explain the differences between what people thought about health and medical care in 1918 and what they think now, by studying the information that has been provided.

\begin{tabular}{|l|l|l|}
\hline & What people did in $\mathbf{1 9 1 8}$ & $\begin{array}{c}\text { What the generally accepted } \\
\text { situation is now }\end{array}$ \\
\hline $\begin{array}{l}\text { Hanging garlic around your } \\
\text { neck, eating lemons }\end{array}$ & & \\
\hline Isolation and quarantine & & \\
\hline Wearing masks & & \\
\hline $\begin{array}{l}\text { Treatment at home or in } \\
\text { hospital }\end{array}$ & & \\
\hline $\begin{array}{l}\text { Those in crowded and } \\
\text { inadequate housing }\end{array}$ & & \\
\hline Doctor's visits to home & & \\
\hline $\begin{array}{l}\text { Everyone kept up to date } \\
\text { with news and information }\end{array}$ & & \\
\hline
\end{tabular}

Drawing on JH Hexter (1971), Dean (2004) summarises the role of a "second record" (which in this case is the information that students have personally experienced and gleaned about period of COVID-19 in 2020)

23 Foster (2013:9) provides a useful list of what professional historians consider in change and continuity, viz. the balance between change and continuity, a strong temporal dimension, the direction of change, the significance of change, descriptive not explanatory analysis. 
in interpreting the past (in this case the 1918 sources, which are the first record):

The second record comprises all the mental attributes and experience the historian brings to bear when working on the first record. The second record determines how the first record is viewed, interpreted and amplified... (Dean, 2004:101).

Students will consciously or unconsciously make use of everything that they have experienced in the 2020 pandemic. The will not, however, all agree on "What the generally accepted situation is now", nor will they necessarily agree on "What people did in 1918", but the discussion of these issues will enable them to construct a better understanding of the flu epidemic and, as they do so, they will inevitably be drawn into its realities of dying and death.

\section{Human dignity}

There are many examples of a lack of dignity in the sources, particularly in the handling and burial of those who died in the epidemic. Death is the ultimate indignity and October 1918 presented very harsh options regarding the living and the dead. To what extent should the dignity of the dead be sacrificed in order to give the living a better chance of survival? This exercise approaches human dignity from the point of view of the human rights (the South African Bill of Rights) of and responsibilities (the African Charter on Human and Peoples' Rights) to the dying and the dead. It deliberately does not prescribe the content or emphasis, leaving it to the class and the individual student, providing wide scope for responses.

By studying the information provided, consider what "human dignity" is.

Read the following statements and discuss or/and write briefly about some of the statements and how they may be relevant to the time of the flu epidemic and to human dignity in 1918. Select at least two statements, one from each document.

Statements in the South African Bill of Rights (1996)

a. Everyone has inherent dignity and the right to have their dignity respected and protected. (10)

b. Everyone has the right to freedom of conscience, religion, thought, belief and opinion. (15 1)

c. Everyone has the right to freedom of movement. (21)

d. Everyone has the right to have access to health care services... No one may be refused emergency medical treatment. (27 1.a) 
e. Everyone has the right of access to any information held by the state... (32 1. a)

Statements in the African Charter on Human and Peoples' Rights (1986)

a. Every individual shall have duties towards his family and society, the State and other legally recognized communities and the international community. The rights and freedoms of each individual shall be exercised with due regard to the rights of others.... $(271,2)$

b. Every individual shall have the duty to respect and consider his fellow beings without discrimination, and to maintain relations aimed at promoting, safeguarding and reinforcing mutual respect and tolerance. (28)

c. The individual shall also have the duty to preserve the harmonious development of the family and to work for the cohesion and respect of the family.... $(29,1)$

\section{Empathy}

Drawing attention to human dignity leads to empathetic understanding. The sharing of a common humanity with others is the starting place; the challenge is to enhance the students' awareness of others (Siebörger, 2020:71). At this point students should have been sufficiently prepared to face having to deal directly with dying and death. Allowing them to make their own choice of source material for the exercise, it is suggested, will make it simpler (and possibly more palatable and/or interesting) for them to engage with the exercise.

Empathy is when we try to understand the situations that faced people long ago and to explain why life was different for them than it is for us. We realise that it is not possible to put ourselves in the position of someone who lived at a different time and place, so we do not pretend that we are the same as they were.

Choose ONE of the sources of information (1-14) to write or talk about. It should be the passage that you think helps you understand best what happened in 1918, OR which speaks to you (and your feelings) the most, OR which reminds you most of something that you yourself have experienced or seen, OR which you think is the most reliable or accurate. Explain what it is that makes you have empathy with a person (or with people) in the passage.

Empathy as a concept in history education has had a chequered and contested existence. It flourished in the 1970s and early '80s (see Knight, 1989), dropped from sight in the 1990s and has now been critically reinterpreted and rehabilitated. Lee and Shermilt (2011) describe the challenges posed by it for students as: 
- making sense of human behaviour;

- understanding why practices that seem irrational and unreasonable today were common in the past; and

- grasping what does and does not count as an empathetic explanation.

It is useful to clarify what aspects of empathy are called upon in this instance. Students will not necessarily have to make sense of people's behaviour in 1918 (though they might well find themselves both puzzled and incredulous by it), but they will, secondly, have to adapt their thinking to the highly unusual circumstances. There is certainly some understanding of irrational and unreasonable circumstances involved. The third aspect, grasping what does and does not count as empathetic explanation, is beyond the scope of this exercise.

\section{Remembrance}

The theme of remembrance is not unfamiliar in school history education literature (see Lyon, 2007, ${ }^{24}$ Freeman, 2014 and McKay, 2017, for example), though it is usually associated with victims of warfare or circumstances where people have done something commendable and exceptional, deserving of commemoration, memorialisation or public acknowledgement and recognition. This is not the case with the $1918 \mathrm{flu}$ epidemic and the conditions of the epidemic made it even less likely that the people who died would be remembered. There were instances among the accounts of the 126 informants in Howard Phillips' research where, as in Source 15, a particular person was remembered but they were very few. He noted, however, that Sol Plaatje had dedicated his novel Mhudi (1930) to the memory of his daughter Olive, who died in 1921, probably of the after-effects of the flu (Phillips, 2018:95).

How do we remember people after they have died? And how do people who live long after them (102 years in this case) remember them?

Have a discussion in class around these three questions as they relate the 1918 flu, paying attention also to how they overlap with each other, as the diagram illustrates:

24 Lyon (2007:46) poses the question of whether remembrance [as related to those who died in the two World Wars] should still be encouraged in history teaching, as (a) it is important for history teachers to ask provocative questions, (b) it reveals that history matters, and, (c) it is appropriate to question whether remembrance is still relevant for young people of a different millennium. 


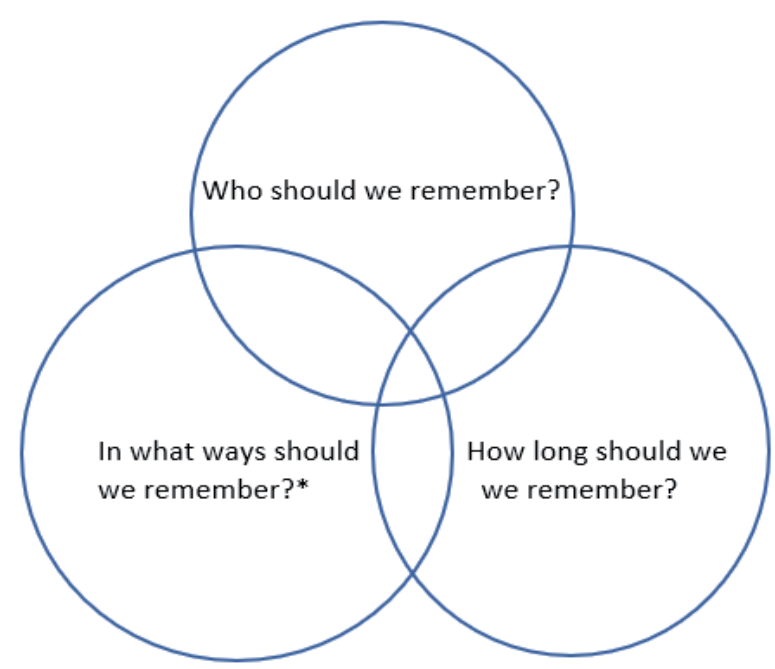

Source: Developed by the authors.

* Ideas could include anniversaries, memorials, gravestones, notices in newspapers, books, websites and on Facebook, for example.

Remembrance provides the opportunity to focus on one's own beliefs and practices and to move away from considering death itself. It carries with it the positive element that there might be something after death (as many religions remember and acknowledge the dead in their worship) and that those living in the present might have a responsibility to those who have died before them - if for no other reason than that those who are alive today have benefitted by what medical science learned during the 1918 epidemic. One reason why there have been far fewer COVID-19 deaths than 1918 flu deaths is because the health professions could manage the disease far better, on the basis of better knowledge and experience gained from the past.

\section{In conclusion: Should one teach about dying and death in this way?}

We approached the question with a number of aims in mind. The first was to raise the level of knowledge about the 1918 flu epidemic in South Africa, particularly in the light of the fact that media often portray 1918 and 2020 as being similar in many respects ("It happens about once a century...", for instance). When one attempts a direct comparison of the two one is forced to consider how brutal the flu of October 1918 was and how unimaginable it must have been for many people, in ways which cannot be equated with 2020. Secondly, we were challenged by the pedagogical difficulties that 
1918 presented. Was it a suitable topic for the classroom? How could students be immersed in that level of reality? But having grasped that the heart of the issue is human mortality and that death and dying are central to all notions of history, the third aim was to explore "ways in" to the topic that would both not appear to be too demanding, too hard, or disrespectful.

The final aim is that having devised the sequence of five themes and provided exemplars to illustrate the means in which they can be employed, we hope that others might take this further and trial and adapt the exemplars in the classroom, thus contributing to a literature of practice regarding the pedagogy of dying and death in school history teaching.

\section{References}

Alhadeff, V 1976. A Newspaper History of South Africa. Don Nelson: Cape Town.

Burman, J 1970-1976. Influenza. Standard Encyclopaedia of Southern Africa. Cape Town: Nasou.

DBE 2011. Curriculum and Assessment Policy Statement History Grades 10-12. Pretoria: Department of Basic Education. Available at: https://www.education.gov. $\mathrm{za} /$ Portals/0/CD/National $\% 20$ Curriculum $\% 20$ Statements $\% 20$ and $\% 20$ Vocational/CAPS\%20FET\%20\%20HISTORY\%20GR\%2010-12\%20\%20 WeB.pdf?ver=2015-01-27-154219-397. Accessed on 28 September 2020.

Dean, J 2004. Doing history: Theory, practice and pedagogy. In: S Jeppe (ed.), Toward New Histories for South Africa. On the place of the past in our present. Cape Town: Juta Gariep.

Faust, D 2008. This Republic of Suffering. Death and the American Civil War. New York: Random House.

Foster, R 2013. The more things change, the more they stay the same: Developing students' thinking about change and continuity. Teaching History, (151):8-17.

Freeman, J 2014. Remembering the First World War: Using a battlefield tour of the Western Front to help pupils take a more critical approach to what they encounter. Teaching History, (155):45-52.

Hammond, K 2001. From horror to history: Teaching pupils to reflect on significance. Teaching History, (104):15-23. 
Hexter, J 1971. The History Primer. New York: Basic Books.

Knight, P 1989. Empathy: Concept, confusion and consequences in a national curriculum. Oxford Review of Education, 15(1):41-53.

Lee, P and Shermilt, D 2011. The concept that dares not speak its name: Should empathy come out of the closet? Teaching History, (143):39-49.

Lyon, G 2007. Is it time to forget remembrance? Teaching History, (128):46-51.

McKay, C 2017. Active remembrance. The value and importance of making remembrance relevant and personal. Teaching History, (166):20-27.

Phillips, H 1990. 'Black October': The impact of the Spanish Influenza Epidemic of 1918 on South Africa. Pretoria: Government Printer.

Phillips, H 2012. Plague, pox and pandemics. A Jacana Pocket History of Epidemics in South Africa. Auckland Park: Jacana.

Phillips, H (ed.) 2018. In a time of plague. Memories of the 'Spanish' Flu epidemic of 1918 in South Africa. Cape Town: Van Riebeeck Society.

Siebörger, R 2020. “But they can’t do that!” Practical approaches to engage South African primary school pupils in historical learning. In: W Berg \& T Christou (eds.), The Palgrave Handbook of History and Social Studies Education. Cham, Switzerland: Palgrave Macmillan. 